\section{Regards sur l'économie allemande}

Bulletin économique du CIRAC

$84 \mid 2007$

Varia

\title{
Economie sociale de marché
}

von HAUFF Michael (ed), Die Zukunftsfähigkeit der Sozialen

Marktwirtschaft/ LAUK Kurt J. (ed), Was würde Ludwig Erhard heute sagen?

\section{(2) OpenEdition}

Édition électronique

URL : http://journals.openedition.org/rea/417

DOI : $10.4000 /$ rea. 417

ISBN : 978-2-8218-0864-5

ISSN : 1965-0787

\section{Éditeur}

CIRAC

Édition imprimée

Date de publication : 1 décembre 2007

ISSN : 1156-8992

\section{Référence électronique}

"Economie sociale de marché », Regards sur l'économie allemande [En ligne], 84 | décembre 2007

document 2, mis en ligne le 22 avril 2008, consulté le 22 septembre 2020. URL : http://

journals.openedition.org/rea/417 ; DOI : https://doi.org/10.4000/rea.417

Ce document a été généré automatiquement le 22 septembre 2020.

(c) CIRAC 


\title{
Economie sociale de marché
}

\author{
von HAUFF Michael (ed), Die Zukunftsfähigkeit der Sozialen
}

Marktwirtschaft/ LAUK Kurt J. (ed), Was würde Ludwig Erhard heute sagen?

\section{RÉFÉRENCE}

von HAUFF Michael (ed), Die Zukunftsfähigkeit der Sozialen Marktwirtschaft, Metropolis-Verlag, Marburg, 2007, 396 p.

LAUK Kurt J. (ed), Was würde Ludwig Erhard heute sagen? Hohenheim Verlag, Stuttgart/Leipzig, 2007, 275 p.

1 Voilà deux ouvrages de référence sur l'économie sociale de marché, parus dans le contexte de la négociation des programmes fondamentaux des partis CDU et SPD (voir dans ce numéro). L'un rappelle que le mode d'organisation auquel l'Allemagne doit sa prospérité et son modèle social est non seulement perfectible, mais doit surtout s'adapter à un monde désormais globalisé; il expose les principaux axes de réformes (von HAUFF). L'autre, publié sous la direction du président du conseil économique de la CDU (LAUK), éclaire les principes fondateurs de la doctrine ordo-libérale à la lumière des défis du XIX Parmi les auteurs figurent la Chancelière, le Cardinal Lehmann, des professeurs d'université ou des entrepreneurs. Les propos sont agrémentés d'une interview fictive de Ludwig Erhard, portant notamment sur l'Europe ou la mondialisation. A lire absolument... (ib) 